\title{
Exploration of Swampland Plants in South Kalimantan and Its Toxicity Against Armyworms (Spodoptera sp.)
}

\author{
ILHAMIYAH*), GUSTI KHAIRUN NI'MAH, ANA ZURAIDA, AND ARI JUMADI KINARDI
}

Faculty of Agriculture, Kalimantan Islamic University of Muhammad Arsyad Al Banjari, Banjarmasin.

\begin{abstract}
This research aims explored swampland plants in South Kalimantan which have potential as a botanical pesticides and compared the levels of toxicity between the swampland plants extracts against armyworms (Spodoptera sp). The exploration of plants that have the potential as botanical pesticides was carried out in the swamps of South Kalimantan, while the toxicity test was carried out in the Basic Laboratory of the Kalimantan Islamic University of Muhammad Arsyad Al Banjari Banjarmasin. The research was carried out by exploring plants that have the potential as botanical pesticides carried out by collecting samples of swampland plants in South Kalimantan which are commonly used by rural communities as materials for controlling insects such as mosquitoes and plant pests, plants used for traditional medicine, plants used for kill animals for example to find fish. The plants found identified to species level, at least to the family level, then a toxicity test were carried out to determine the $\mathrm{LC}_{50}$ by probit analysis. The results of this research showed that there are 3 plant spesies of plant that have the potential as botanical pesticide, namely karamunting (Melastoma malabathricum); gelinggang (Cassia alata); and galam (Melaleuca cajuputi). The basis for the selection of South Kalimantan swampland plants is plants that are commonly used by the community as an ingredient for controlling insects such as mosquitoes and plant pests. The highest levels of toxicity between the extracts of all swampland plants in South Kalimantan to armyworms (Spodoptera sp) were galam (Melaleuca cajuputi) with $429.04 \mathrm{~g} / 1$ of $\mathrm{LC}_{50}$; then karamunting (Melastoma malabathricum) with $447.995 \mathrm{~g} / 1 \mathrm{LC}_{50}$, while the lowest toxicity was gelinggang (Cassia alata) with $498.301 \mathrm{~g} / 1 \mathrm{LC}_{50}$.
\end{abstract}

Keywords: Probit analysis, $\mathrm{LC}_{50}$, toxicity, exploration, swampland

\section{INTRODUCTION}

Pests are an important limiting factor in efforts to increase agricultural crop production. Pest attacks occur at all stages of agricultural crop cultivation, starting from before planting, in planting, to storing and transporting the products. People are familiar with the names of vegetable pests, such as cabbage leafworms,

Correspondence: Ilhamiyah; Faculty of Agriculture, Kalimantan Islamic University of Muhammad Arsyad Al Banjari, Jln. Adyaksa

Kayu Tangi, Banjarmasin (70123), Indonesia;

Email: iililhamiyah@gmail.com.

Journal of Wetlands Environmental Management

Vol 9, No 1 (2021) 21 - 28

http://dx.doi.org/10.20527/jwem.v9i1.256 leafminer flies, aphids, blight, bacterial wilt disease, swollen root disease, potato cyst nematode and many more. It is estimated that the loss of agricultural crops due to pest attack in the plantations ranges from $25 \%$ to $100 \%$ of the potential yield. In addition to great reduction in product quantity, pest attacks can also reduce product quality, as well as product competitivenessin the market. As a result, this economic loss reaches billions of rupiah every year (Setiawati et al., 2008). 
Responding to the economic losses of agricultural farming due to pest attacks, farmers generally still rely heavily on the use of synthetic chemical pesticides, even though Integrated Pest Management (IPM) has become a government policy. They still follow the conventional crop protection paradigm, a preventive and insurance principles that tend to be excessive. The use of pesticides that are not correct and the correct type and dose of use often cause pest problems and pest explosions, including the occurrence of pest resistance, pest resurgence, secondary pest explosions, pesticide residues, and human health problems (Untung, 1993).

Consumer's awareness of agricultural products safety are increasing recently. These have been encouraging the development of various techniques in order to produce environmentally friendly agricultural products those also safe for human consumption. The technique includes the development of botanical pesticides.

Botanical pesticides derived from swampland crops are very important in pest control towards environmentally sound agriculture. Botanical pesticides are actually the local wisdom of the Indonesian people, because many people already know the types of plants that can be used to control plant pests, but they are not developed enough, while Indonesia is rich in biodiversity. This study aims to explore swampland plants in South Kalimantan which have the potential as vegetable pesticides; and comparing the level of toxicity between South Kalimantan swampland plants found against armyworms (Spodoptera sp)

Armyworms (Spodoptera $\mathrm{sp}$ ) is a type of polyphagous insect pest, including the
Noctuidae family.

The larvae are known to be very destructive pests. However, there are no reports on botanical pesticide from swampland plants. This study aimed at exploring swampland plants in South Kalimantan which have potential as a botanical pesticide; and comparing the levels of toxicity between the extracts of swampland plants found in South Kalimantan against armyworms (Spodoptera $\mathrm{sp}$ ).

\section{MATERIALS AND METHODS}

\section{Place and Time of Research}

The exploration of plants that have the potential as botanical pesticides was carried out in the swamps of South Kalimantan (Figure 1). Toxicity test was carried out in the Basic Laboratory of the Islamic University of Kalimantan Muhammad Arsyad Al Banjari, South Kalimantan.

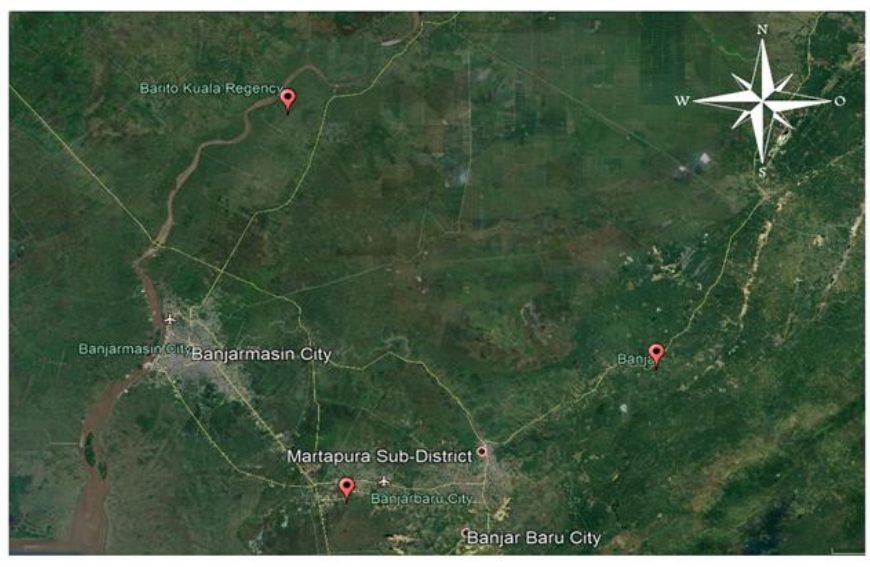

INFORMATION :

: sampling AREa

\section{Preparation}

The leaves were first selected and washed thoroughly, thinly sliced, then were blended 
with distilled water until smooth. The blended material was allowed to stand for 24 hours, then was filtered using a sieve to obtain a solution of plant material.

\section{Exploration of Plants with Active Pesticide Ingredients}

Exploration of plants that have the potential as botanical pesticides was carried out by collecting samples of swampland plants in South Kalimantan which are commonly used by rural communities as materials for controlling insects such as mosquitoes and plant pests, plants used for traditional medicine, plants used to poison animals,. The plants found were then identified to determine the Latin name, at least to the family level.

\section{Toxicity Test}

Toxicity test was carried out by the orders dercribed below:

a. We prepare a solution of plant extracts with five different concentrations using a water diluent.

b. The ten third instar larvae were placed in a glass cylinder topped with gauze.

c. Using a pipette, evenly drop $5 \mathrm{ml}$ of the plant extract liquid onto the body of the third instar larvae.

d. After 10 seconds of contact, dry the caterpillar by draining the glass cylinder on the tissue paper.

e. Enter armyworm food in the form of mustard leaves in a plastic cup, then put the treated larvae into the plastic cup. The number of larvae given each treatment was 10 third instar larvae.

f. Observations were made 24 hours after the larvae received plant extracts. The number of dead larvae was finally counted and represented in percent (\%) unit.

Based on the data on insect mortality in preliminary experiments, the concentration of the solution was taken that could kill $20-90 \%$ of the third instar larvae population. The treatment method was as in the preliminary test using 30 third instar larvae for each concentration. Observations were made 24 hours after the larvae were given plant extracts. The data were analyzed using probit analysis by determining the $\mathrm{LC}_{50}$ value.

The $\mathrm{LC}_{50}$ value can be determined by the Probit Method (USEPA, 2002). The $\mathrm{LC}_{50}$ value is obtained by entering the concentration in the test results and how many deaths of test larvae at each concentration and control in the Probit analysis. Probit analysis using SPSS version 17.0 software.

\section{RESULTS AND DISCUSSION}

\section{Exploration of South Kalimantan Swampland Plants}

Based on the exploration results of swampland plants in South Kalimantan which have potential as botanical pesticides, it was found that there were three types of plants, namely keramunting (Melastoma malabathricum); gelinggang (Cassia alata); galam (Melaleuca leucadendra) (Figure 2). 


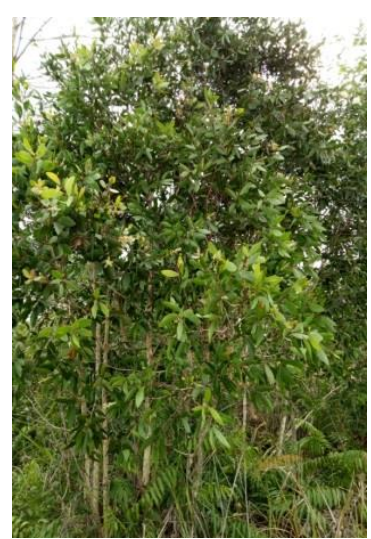

A

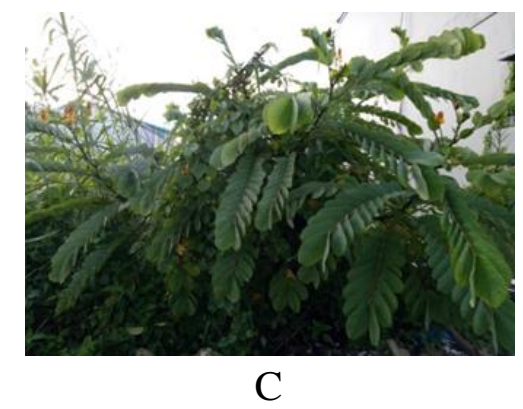

Figure 2.

A. Galam (Melaleuca leucadendra); B. Keramunting (Melastoma malabathricum); C. Gelinggang (Cassia alata);

Galam (Melaleuca leucadendra) is a plant that can grow to a height of about 35-40 meters, and its diameter can reach $30-35 \mathrm{~cm}$. Galam plant stems will look like layers and grayish white in colour. Galam leaves are single-leaf plants, the leaves have short stalks with lanceolate or oval leaf blades. On the surface of the leaves have fine hairs. The leaves are light green to dark. The flowers are classified as compound which is shaped like a bell in the form of a bell and the crown is white. The pistil. yellow. The fruit is known as galam or micro-hole fruit because the fruit looks like a small hole and a small antenna in the middle. The color of the fruit varies, some are easy green and the color of the fruit is brownish green, small in shape that appear in groups on one stalk and elongate, amounting to 20-30 pieces (Onan, 2010).

Karamunting (Melastoma malabathricum) is a plant that grows wild in a place that gets enough sunlight. This plant is usually found up to an altitude of 1,650 meters above sea level. The characteristics include in the clumps group, single leaf, elliptical shape extending to oval, sitting opposite crossed leaves, hairy leaf surface when touched feels rough, rounded leaf base, flat leaf edge, tapered leaf tip. Flowers including compound flowers are reddish purple, the fruit is edible and has small seeds.

Gelinggang (Cassia alata L.) is a large shrub that grows wild in humid places. The leaves are large in the form of even pinnate compound leaves, unpleasant smell, stiff leaflets, 5-12 rows of breech eggs in pairs, $3-15 \mathrm{~cm}$ long, $2.5-9 \mathrm{~cm}$ wide, blunt leaf tips, base slanted leaves, flat leaf edges, $2 \mathrm{~cm}$ long petiole. Flowers are arranged in long, upright bunches, located at the ends of the branches with bright yellow bearna flower crown. The fruit is a flat, black pod with wings on both sides, cracks when it is ripe and contains 50-70 seeds (Arisandi \& Yovita, 2006).

\section{Preliminary Test}

The results of preliminary test are given in Figure 3. 


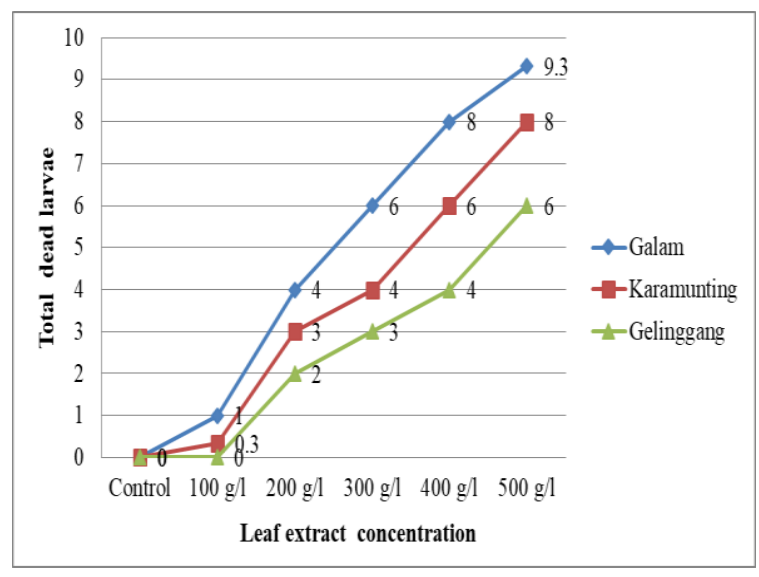

Figure 3. Preliminary Test of the Average Mortality of Larvae Spodotera $s p$

Figure 2 shows that in the preliminary test, it was found that the extract concentration of 100 $\mathrm{g} / \mathrm{l}$ of water, on average, killed the larvae of Spodotera sp in the three types of swampland plants, namely galam (M. cajuputi); keramunting (M. malabathricum); and Gelinggang $(C$. alata) was below 2 (i.e., $<20 \%)$. Meanwhile, the extract concentration of the three types of swampland plants with $200 \mathrm{~g} / \mathrm{l}$; $300 \mathrm{~g} / \mathrm{l} ; 400 \mathrm{~g} / \mathrm{l}$ and $500 \mathrm{~g} / \mathrm{l}$ were ranged from 2.0 to 9.3 (i.e., above $20 \%$ ).

\section{Testing}

Figure 3 showed mortality rate of the third instar larvae population with 30 larvae for each concentrations.

Journal of Wetlands Environmental Management Vol 9, No 1 (2021) 21 - 28

http://dx.doi.org/10.20527/jwem.v9i1.256

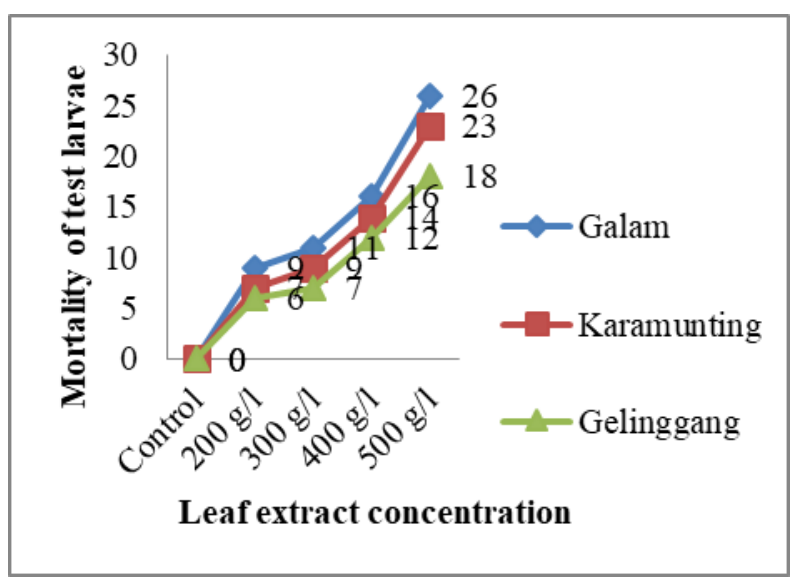

Figure 4. Testing Results of mortality of Spodoptera sp. Larvae

The results of the Lethal Concentration 50 $\left(\mathrm{LC}_{50}\right)$ test were as follows:

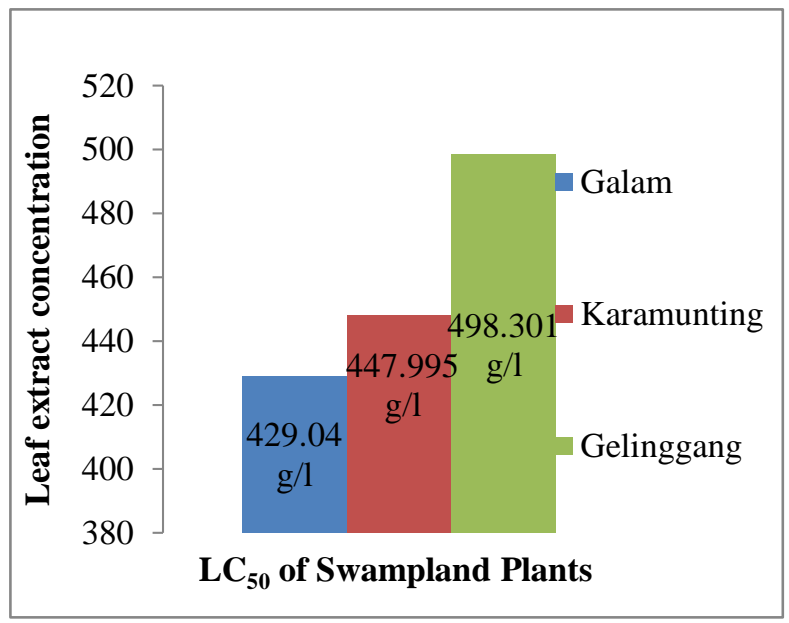

Figure 5. Probit Analysis Results

Toxicity levels of the three South Kalimantan swampland plants found against armyworms (Spodoptera sp) the highest was Galam (Melaleuca leucadendra) with an $\mathrm{LC}_{50}$ of $429.040 \mathrm{~g} / \mathrm{l} ; \quad$ then Karamunting ( $M$. malabathricum) with an $\mathrm{LC}_{50}$ of $477.995 \mathrm{~g} / \mathrm{l}$ and the lowest toxicity was Gelinggang $(C$. alata) with an $\mathrm{LC}_{50}$ of $498.301 \mathrm{~g} / \mathrm{l}$ (Figure 5).

The results of observations on galam leaf extract showed an averaged $\mathrm{LC}_{50}$ of $429,040 \mathrm{~g} / \mathrm{l}$, which means that with a concentration of galam 
leaf extract of $429,040 \mathrm{~g} / \mathrm{l}$ was able to kill $50 \%$ of the test larvae. At the beginning of the test, the larvae did not show an appetite for consuming the feed (i.e., mustard leaves which had been soaked with galam leaf extract). The test larvae started to feed on mustard leaves soaked in galam leaf extract after 24 hours. The test larvae that lose their appetite are thought to be due to the presence of an anti-feedant in galam leaf extract, a compound that can temporarily or permanently stop appetite. Antifeedant compounds do not kill, repel or trap insect pests, but only inhibit the insect's appetite, so that agricultural crops can be protected (Ling, et al., 2008). Additionally, antifeedant compounds are very specific to target insect pests, so it is safe for other insects as natural enemies, parasitoids and other neutral insects. Insect pest control using compounds that inhibit feeding activity provides several advantages such as not causing resistance, high selectivity, easily degraded, and relatively nontoxic to humans (Leatemia and Murray, 2004; Ling, et al., 2008).

Table 1. Percentage of phytochemical content of Karamunting leaf extract ( $M$. malabathricum) Based on the results of analysis using GCMS (Gas Chromatography Mass Spectrometry) (Kartina, et al. 2019)

\begin{tabular}{llc}
\hline No. & Identified compound & Percentage \\
\hline 1. & Phenol & 36.32 \\
2. & Fatty Acid & 20.74 \\
3. & Terpenoids & 9.13 \\
4. & Sterols & 5.77 \\
5. & Alkaloids & 4.80 \\
6. & Amino acid & 3.50 \\
7. & Alcohol & 1.54 \\
8. & Other compounds whose & 1.05 \\
& numbers are classified as low \\
\hline
\end{tabular}

Karamunting leaf extract also showed an average $\mathrm{LC}_{50}$ of 447,995 g / 1, which means that the karamunting leaf extract concentration of $447,995 \mathrm{~g} / \mathrm{l}$ was able to kill $50 \%$ of the test larvae. This is because karamunting leaf extract contains alkaloid and terpenoid compounds (Kartina, et al., 2019) based on analysis using GCMS (Gas Chromatography Mass Spectrometry) (Table 1). Phenolic compounds in plants are important in plant physiology because they play a role in pigmentation, taste, for growth, reproduction and plant resistance to pathogens and predators (Blomhoff, 2010).

Karamunting also contains secondary metabolite compounds, compounds that are smaller in size and are produced in plant cells in very limited quantities. Secondary metabolite compounds such as alkaloids, saponins and phenol group compounds are polar so that they can dissolve in polar or semi polar solvents, such as methanol solvent. Each secondary metabolite compound has a different work capacity as an insecticide with various mechanisms. Bintaro plants can be used as an alternative to vegetable insecticides to reduce product losses (Yan et al., 2011 and Wiratno et al., 2011). According to Yunita (2009), Cerbera odollam leaf extract is also suspected to contain secondary metabolites (i.e., phenolic compounds) which function as insect-eating repellents, though they can also act as feeding stimulants in other insects.

While, terpenoid compounds are one of the natural chemical compounds that are widely used as medicine. There are many known roles of terpenoids from plants, such as inhibiting the growth of competing plants and as insecticides against insect pests. Alkaloid and terpenoid compounds have the potential to inhibit food and are toxic, causing pests tend to be quiet

(Astriani, 2010). The role of sterols for 
Spodoptera litura is a precursor to the ecdison hormone. With a decrease in the supply of steroids, the skin molting process of Spodoptera litura will also be disturbed. As a result, there is a disruption in the growth and development of Spodoptera litura trying to reduce the disturbance that occurs by extending the period of development (Fadlilah \& Rakhmah, 2012).

The leaf extract of gelinggang ( $C$. alata) was able to kill half number of the test larvae at average constration of $498.301 \mathrm{~g} / \mathrm{l}$. Jayuska, et al. (2004) states that gelinggang (or ketepeng in Chinese) leaf extract contains chemical compounds including alkaloids, saponins, flavonoids, tannins, terpenoids, and anthraquinones. Several studies have stated that ketepeng is an anti-fungal plant (acting as a fungicide) due to the presence of tannins. Meanwhile, compounds such as terpenoids and flavonoids contained in the leaf extract are antifeedant compounds that can make the test larvaegoes on hunger strike. According to Schoonhoven (1982) alkaloids and terpenoids are very potential as food inhibitors in some insects. Some researchers say that a compound that has anti-food activity appears to have an effect on concentrations that can inhibit eating by up to $50 \%$ (Rose et al., 1981 in Schoonhoven, 1982). However, some other researchers say that anti-eating compounds are considered as effective if they can inhibit eating about 80-100\% (Schoonhoven, 1982).

\section{CONCLUSIONS}

This research concluded, that:

1. Swampland plants in South Kalimantan which have potential as botanical pesticides included 3 types, namely keramunting
(Melastoma malabathricum); gelinggang (Cassia alata); galam (Melaleuca cajuputi).

2. The level of toxicity of the examined swampland plants in South Kalimantan to armyworms (Spodoptera sp) was galam (Melaleuca cajuputi) with an $\mathrm{LC}_{50}$ is $429,040 \mathrm{~g} / \mathrm{l}$, karamunting (Melastoma malabathricum) with an $\mathrm{LC}_{50}$ is $447,995 \mathrm{~g} / \mathrm{l}$, and gelinggang (Cassia alata) with an $\mathrm{LC}_{50}$ is $498.301 \mathrm{~g} / \mathrm{l}$, in this order.

\section{ACKNOWLEDGMENT}

This research was supported funding by Kalimantan Islamic University of Muhammad Arsyad Al Banjari, Banjarmasin, Indonesia (contract No. 047/UNISKA-PUSLIT/I/2020).

\section{REFERENCES}

Arisandi, Y and Yovita A. 2006. Efficacy of medicinal plants. Jakarta: Pustaka Baru.

Blomhoff, R. 2010. Role of Dietary Phytochemicals in Oxidative Stress: The Norwegian Academy of Science and Letters. Proceedings from a Symposium.

Fadlilah, Rakhmah A.N. 2012. Effect of Tembelekan (Lantana camara) Leaf Extract on Growth and Mortality of Grayak Caterpillars (Spodoptera litura) in Soybean. Thesis. Department of Biology, Sepuluh Nopember Institute of Technology, Surabaya.

FWI dan GFW. 2001. Portrait of Indonesian Forests Condition.. Bogor, Indonesia:

Forest Watch Indonesia and Washington D.C. Global Forest Watch. https://wriindonesia.org/sites/default/files/keadaan_hu tan_prolog.pdf

Jayuska, A., Gusrizal, dan Linda R., 2004. Production of Oligoresveratrol Cytotoxic 
Chemicals from Wood Cassia alata Linn. Traditional Medicine of the Dayak Community of West Kalimantan, Basic Science Research, Faculty of Mathematics and Natural Sciences, Tanjungpura University, Pontianak.

Kartina, Shulkipli, Mardhiana, S. Egra. 2019. Potential of karamunting extract (Melastoma malabathricum L.) as a vegetable insecticide to control grayak caterpillars (Spodoptera litura F.). Agrotekma: Journal of Agrotechnology and Agricultural Sciences, 4: 28-41.

Leatemia, J. A.and Murray, B. I.,2004., Toxicity and antifeedant activity of crude seed extracts of Annona squamosa (Annonaceae) against lepidopteran pests and natural enemies. International Journal of Tropical Insect Science, 24:150-158.

Ling, B., Guo-cai, W., Ji, Y., Mao-xin, Z., andGuang-wen, L. 2008. Antifeedant activity and active ingredients against plutellaxylostella from Momordica charantia leaves. Agircultural Sciences in China,7:1466-1473.

Syamsuhidayat,S dan Ria, J. 1991. Inventory of Indonesian Medicines. Jakarta, Mogeraw Hill.Inc

Setiawati, W., K. Udiarto, dan T.A. Soetiarso. 2008. Effect of varieties and planting systems of red chili on suppression of whitefly pest populations . J. Hort., 18: 5561.

Steenis, V. 2008. Flora for schools in Indonesia.Jakarta: PT. Pradnya Paramita.

Untung, K. 1993. Integrated Pest Management Concept. . Andi Offset. Yogyakarta.150 p.
USEPA (United States Environmental Protection Agency). 2002. Method for Measuring the Acute Toxicity of Effluents and Receiving Waters to Freshwater and Marine Organism. Fifth Edition. EPA-821-R-02-012. Office of Water (43035). Washington, DC. $266 \mathrm{p}$

Tarmadi, D., AH. Prianto, I. Guswenrivo, T. Kartika, S. Yusuf. 2007. Effect of Bintaro Extract (Cerbera odollam Gaertn.) And Kecubung (Brugmansia candida Pers) on Captotermes sp. J. Trop. Wood Scie. \& Tech., 5.

Whitmore, T.C., 1975. Tropical Rain Forests of the Far East. Clarendon Press. Oxford.

Whitten T., S.J. Damanik, J. Anwar dan N. Hisyam, 1997. The Ecology of Sumatra. Periplus Editions (HK) Ltd. Singapore.

Yan, X., F. Tao, dan T. W. Ping. 2011. Chemical Constituents and Bioactivity of Mangrove Plants in the Genus Cerbera. Journal of Guangxi Academy of Science, 28: 55-61.

Yunita, JEA., NH.Suprapti, JS. Hidayat. 2009. Leaf Extract Teklan (Eupatorium riparium) on Mortality and Development of Aedes aegyptii. Hioma, 11: 11-17 